\title{
Eaters of Opium
}

\author{
Connie Nugent MLS, Gilbert Berdine MD
}

Opioid misuse has become a national epidemic, but the use of opium and its derivatives to relieve pain or to induce feelings of euphoria has a long history. Ancient Sumerians cultivated the poppy as early as 3400 BCE and referred to it as the "joy plant." By 1300 BCE, the Assyrians, the Babylonians, and Egyptians had introduced opium to the countries bordering the northern shores of the Mediterranean and into Europe. Centuries later, Hippocrates noted the usefulness of opium in treating pain, and Alexander the Great brought the narcotic into Persia and India. By the 1500s CE, Paracelsus treated patients with laudanum, the "stones of immortality." In 1821, Confessions of an English Opium-Eater was published, a first person account of Thomas de Quincey's struggles with addiction. Morphine, a derivative of opium, was first administered by syringe in 1843, which provided a stronger effect. Heroin was synthesized in 1874 ; in the early $20^{\text {th }}$ century in the US, heroin was prescribed as a "step-down" drug to aid in withdrawal from morphine addiction. ${ }^{1}$ Unfortunately, withdrawal from heroin equaled the suffering of morphine withdrawal. Currently, millions of people around the world are victims of opioid addiction, with devastating effects.

In Eugene O'Neill's 1955 play Long Day's Journey into Night, Mary Tyrone, wife of an alcoholic matinee idol, relapses after she has been released from an institution to cure her addiction to morphine. She mentions the need to go uptown, to get something at the drugstore. Her husband angrily replies,

Corresponding author: Connie Nugent

Contact Information: Connie.nugent1@gmail.com

DOI: $10.12746 /$ swrccc.v6i23.464
Leave it to you to have some of the stuff hidden, and prescriptions for more! I hope you'll lay in a good stock ahead so we'll never have another night like the one when you screamed for it, and ran out of the house in your nightdress half crazy, to try to throw yourself off the dock. ${ }^{2}$

Mary realizes that she has changed due to her addiction:

I've become such a liar. I never lied about anything once upon a time. Now I have to lie, especially to myself. But how can you understand, when I don't myself. I've never understood anything about it, except that one day long ago I found I could no longer call my soul my own. ${ }^{3}$

By the end of the play, Mary has retreated so far within herself and into the past that she is unreachable.

While Mary Tyrone's addiction is enabled and protected by her family, her doctor, and her pharmacist, the painting Eaters of Opium (1868) depicts addicts for whom the effects of addiction are all too obvious. During his service with the Imperial Russian Army, war artist Vasily Vereshchagin witnessed the atrocities of combat that he later documented in paintings of nearly photographic quality. The Realism movement in art focuses on portrayals of the real lives of ordinary people. As an anti-war soldier, Vereshchagin painted realistic depictions of the horrors of war; some of his paintings were banned in some areas for fear of inflaming anti-Russian sentiment. ${ }^{4}$

But not all of his paintings featured the effects of warfare. While in Russian-occupied Turkestan, he focused also on the effects of poverty and addiction. Turkey produced vast quantities of opium, and Vereshchagin observed natives who regularly ingested or smoked the narcotic. His realistic style presents the subjects of Eaters of Opium accurately, without 
artifice. Unwashed and in ragged clothing, the addicts huddle together in a small dirty room in varying degrees of lethargy. Some slump completely, while others attempt to stay upright. The central figure seems to look directly at the viewer as if to communicate the hopelessness of their lives. Arrayed in front of them is the detritus of opium consumption. The painting's monochromatic color scheme of muddy browns evokes a sense of decay, and underscores the connection of opium with the death of something that, only recently, was in the prime of life. The "eaters of opium" are not elderly, but appear older than their lifespans.

Opioid addiction has plagued mankind for centuries. Users of opium are frequently trying to disconnect from the painful choices awaiting them in life. This painting illustrates the search for oblivion among addicts in $19^{\text {th }}$ century Turkestan and ties in well with how the current opioid epidemic is prematurely ending the lives of younger people globally.

Keywords: opioids, addiction, Eugene O'Neill, Vasily Vereshchagin

From: Department of Internal Medicine at Texas Tech University Health Sciences Center, Lubbock, TX

Submitted: 4/4/2018

Conflicts of interest: none

This work is licensed under a Creative Commons Attribution-ShareAlike 4.0 International License.

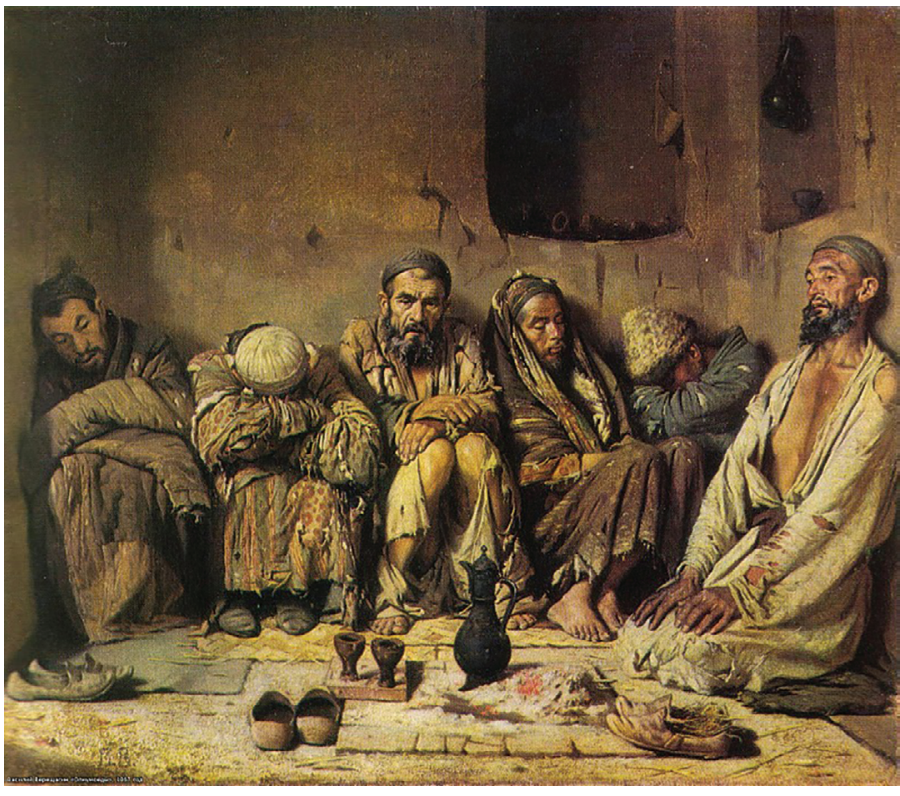

Eaters of Opium. Vasily Vereshchagin. 1868. Fine Arts Museum of Uzbekistan.

https://www.sartle.com/artwork/eaters-of-opium-vasilyvereshchagin.

\section{REFERENCES}

1. "The Opium Kings." Frontline. Boston: Public Broadcasting System. https://www.pbs.org/wgbh/pages/frontline/shows/ heroin/etc/history.html accessed 3/30/2018.

2. O'Neill, Eugene. Long Day's Journey into Night. New Haven, CT: Yale University Press, 1956. p. 86.

3. ibid. p. 93.

4. Vasily Vereshchagin. http://totallyhistory.com/vasily-vereshchagin/) accessed 4/3/2018. 